exposure; the technique of development was identical for all. Undecalcified histological preparations stained by the von Kóssa method, as described by McLean and Bloom ${ }^{2}$, were made from sagittal sections through the knee joint. Litters from five normal untreated rats were similarly examined and served as controls.

The findings in all these animals were comparable to those described by Bloom and Bloom ${ }^{3}$ in embryonic and new-born rats, and we have been unable to detect any differences between rats born from treated and untreated mothers. It is true that there are "striking defects in various parts of the skeleton" of new-born rats, as shown by X-ray examination; but these defects are not peculiar to the offspring from mothers treated with sulphonamides.

Benesch et al. began their work with the hypothesis that sulphanilamide, which inhibits carbonic anhydrase, might interfere with calcification, with the expectation that sulphapyridine, which does not have any effect on this enzyme, would have no effect on the deposition of bone salt. In view of their reported findings, which appeared to indicate that both sulphonamides inhibited calcification, they offered the interpretation that this effect was due to inhibition of the activity of bone phosphatase. Silver and Golding 4 have shown that bone phosphatase is inhibited by sulphonamides in vitro, but the concentrations required (250-1,500 mgm. per cent) and the degree of inhibition (50 per cent or less) would make it extremely unlikely that this mechanism could have physiological significance.

This work was supported by a grant-in-aid from the United States Public Health Service, Research Grants Division.

Depts. of Physiology and Biochemistry,

Zelma Baker Miller

JEROME WALDMAN

FrankLIN C. McLean

University of Chicago, Chicago 37.

${ }^{1}$ Benesch, R., Chance, M. R. A., and Glynn, L. E., Nature, 155, 203 (1945).

McLean, F. C., and Bloom, W., Anat. Rec., 78, 333 (1940)

'Bloom, W., and Bloom, M. A., Anat. Rec., 78, 497 (1940).

- Silver, P. H. and Golding, J. S. R., Lancet, i, 528 (1945).

\section{Bilirubin-Serum Protein Complexes and the van den Bergh Reaction}

ReCenT work by N. H. Martin ${ }^{1}$, showing complex formation between bilirubin and the $x$-globulin as well as the albumin components of plasma, is not only of great theoretical and practical significance from the point of view of the physical chemistry of the proteins, but also may have important implications regarding the interpretation of the van den Bergh reaction. The binding of bilirubin to different plasma protein fractions might be related to the alleged two forms of bilirubin postulated by many workers to explain the different types of direct van den Bergh reaction.

We have examined a small number of jaundiced sera by the electrophoresis technique and can con. firm Martin's findings that a small but definite fraction of the bilirubin migrates with the $\alpha$-globulin fraction, in addition to the migration of the main fraction of the bilirubin with the albumin. In all cases, bilirubin migrated in much the same proportions with the albumin and $\alpha$-globulin fractions respectively, whatever the nature of the jaundice or the type of direct van den Bergh reaction. One of the jaundiced sera we examined was obtained from a patient with retention jaundice and contained $16 \cdot 2$ mgm. bilirubin per $100 \mathrm{ml}$., gave an almost completely negative direct van den Bergh reaction and a directindirect quotient (D.I.Q. $)^{2}$ of 9 by the $30 \mathrm{~min}$. Malloy and Evelyn method. The bilimubin of this serum behaved in the electrophoresis apparatus in pracisely the same way as bilirubin of sera from patients with obstructive jaundice or acute hepatitis and containing similar amounts of bilirubin but giving typical positive direct van den Bergh reactions and D.I.Q. values greater than 50 . We are therefore compelled to conclude that the binding of bilirubin by different fractions of the plasma proteins bears no direct relationship to the nature of the direct van den Bergh reaction.

Department of Biochemistry, King's College Hospital,

London.

C. H. Gray

Lister Institute of

Preventive Medicine,

London.

Nov. 10.

${ }^{1}$ Martin, Biochem. J. Proc. (in the press).

- Gray, Quart. J. Med., 16, 135 (1947).

\section{R. A. Krewwick}

\section{Alkaline Phosphatase in Fish Gut}

SINCE Gomori ${ }^{1}$ and Takamatsu ${ }^{2}$ adopted a histochemical test for the demonstration of alkaline phosphatase, many investigators have examined the distribution of the enzyme in animal tissues; the majority, however, employed material from mammals.

I have recently been studying the distribution of the enzyme in the alimentary tract of certain freshwater fishes, namely, three species of the family Cyprinidæ. The results are not without interest. For example, the concentration of the enzyme varies from species to species as well as in the various segments of the otherwise comparatively uniform intestine. The sites of activity of the enzyme are the free border of the absorptive cells, and the granular cells which are found in the submucosa and which invade the intestinal epithelium (these are known to be derived from granulocyte leucocytes, Duthie ${ }^{3}$ ). The enzyme occurs also in the connective tissue, blood vessels, and in the stratified epithelium lining the buccal and pharyngeal cavities. The presence of the enzyme in the Golgi zone of the absorptive cells is not a constant feature of these fish, contrary to what Emmel ${ }^{4}$, and Deane and Dempsey ${ }^{5}$ have found in certain mammals.

It is generally accepted that the enzyme is involved in a phosphorylation process of glucose $e^{6}$. Its presence in the stratified epithelium, especiully concentrated in the stratum germinativum, is therefore of interest; and it is suggested that in such epithelium, where the intercellular substance is very scanty, glucose may pass into the epithelium by a chemical process of phosphorylation, initiated by the enzyme secreted at its base, rather than by diffusion.

Gomori and Takamatsu incubated the sections with the substrate at $37^{\circ} \mathrm{C}$., which corresponds roughly to the body temperature in mammals. In a few experiments, incubation has been carried out at $28^{\circ} \mathrm{C}$. with fish material, and very good results were obtained; the optimum temperature for the enzyme in cold-blooded vertebrates is not necessarily the 